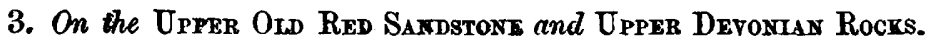
By J. W. Saltze, Esq., F.G.S., A.L.S.

1. Introduction.

Contents.

2. South Pembrokeshire.

3. North Deronshire.

4. Somersetshire, Gloncesshire, and Shropshire.

5. South Ireland.

6. Foreign Equivalents.

7. General Conclusions.

8. Appendix.

\title{
\$1. Introduction.
}

I was engaged for three summer months in 1854 , and again for a short time last year, in examining carefully the lower beds of the Mountain Limestone and the uppermost beds of the Old Red Sandstone, with a view to establish, if possible, the correlation between the Upper Old Red and the corresponding portion of the Devonian series - a relation which has been called in question by good observers.

The memoir of Sedgwick and Murchison * was, indeed, a full statement of the identification of the Old Red Sandstone, as a mass, with the Devonian ; a comparison first suggested by Lonsdale from a consideration of the fossil evidence, and ably supported by Godwin-Austen from his Rhenish explorations, though afterwards called in question by him. The identification is repeated in the later edition of 'Siluria.' Yet, over the North-European districts, there is a singular deficiency of proof of the superposition of the Devonian to the Upper Silurian rocks, and more especially of the gradual passage, at any one point, of the Old Red Sandstone into rocks of the Devonian type.

It has been argued, and with reason, by Sharpet that in Belgium Old Red Sandstone of the ordinary type underlies the whole of the Devonian rocks with marine fossils. The opposite case oceurs in the red conglomerates of the Catskill group in America, which themselves overlie the Devonian. But it has been much overlooked that, in the latter country, the whole Devonian mass, distinguished by its fossils, is clearly superposed on $\mathrm{Dpper}$ Silurian rocks; while it has been by no means certain what part of our great old Red Sandstone group is represented by the red conglomerates either of America or of Belgium. Nor has it been decisively shown that the Old Red Sandstone passes conformably into the strata above or below it; all that could be said with certainty was this-that the Devonian rocks contain fossils of a newer type than the Silurian and overlie them, and that the Old Red Sandstone holds some intermediate place between the Silurian and the Carboniferous rocks.

In this state of the question, the positive identification of any one part of the Old Red series with any one portion of the Devonian became of paramount consequence; since, if we could know the true succession of the Old Red beds as accurately as that of the Devonian rocks has been already traced, we might be able to prove or disprove the correlation of the two series. I have tried to do this, and have, I hope, succeeded.

* "On the Devonian Rocks of the Rhenish Provinces," Trans. Geol. Soc. 2nd ser: vol. v. pp. 633 \&c.

t Quart. Journ. Geol. Soc. vol. ix. p. 18. 
In the measured sections given by Sir H. De la Beche in the 'Memoirs of the Geological Survey'*, those of East and West Pembrokeshire show a clear succession from the Upper Old Red'Sandstone to the Carboniferous Shales. The most complete of these sections are those from Caldy Island and Skrinkle Haven, Tenby, where the whole mass of the Mountain Limestone is underlain by shales and limestones, and these again by the upper beds of the Old Red Sandstone, in unbroken succession. About 150 feet of the latter formation is given in detail. Twenty miles to the west another section, different in detail, but in the main similar, is exhibited in the wild coast-line of West Angle Bay, Pembrokeshiret. The discrepancies, and agreements too, between the different parts of these sections are very striking. I examined them all, and then, crossing the Bristol Channel, took up the corresponding sections on the Barnstaple river and the coast at Croyde Bay. A single fossil in the collections made by Prof. Phillips in West Pembrokeshire gave me the hope of identifying the lowest beds of the limestone-shale with the uppermost Devonian beds, nor was I at all disappointed.

The detailed examinations are written, and wait for publication in the Memoirs of the Geological Survey. I will here confine myself to general statements, somewhat different from those made, on my evidence, in the Anniversary Address of the President of the Geological Society in 1855. In that year I visited the South of Ireland, and, in company with Mr. Jukes, saw ample confirmation of the succession abserved in the North Devon and Pembroke sections. The results obtained are correctly stated in 'Siluria,' 2nd ed., pp. 299, 300. In Mr. Hamilton's Address I had, however, ventured prematurely to identify the Lower Limestone-shales of Pembrokeshire with the Pilton group (uppermost Devonian) of North Devon; and this in the teeth of palæontological evidence which was fully stated, and which ought to have weighed more heavily with me. So exactly similar, however, are the two sections physically, and so exactly does the fauna of one represent the fauna of the other, that I allowed myself to believe that two sets of species, closely allied but actually different, had lived at one and the same time on either side of a barrier so narrow as the width of the Bristol Channel!

This idea, which was backed by the strong conviction and published opinion of Sir H. De la Beche, was in accordance too with the doctrine of marine provinces lately advocated by Prof. Edward Forbes, and there is no wonder that I embraced it.

In the meantime I was enabled to see, in 1857, the Cornish section, and was satisfied that the Upper Devonian group in Britain was divisible into two series *. And I had in Ireland seen the uppermost of these in its true place-beneath the Limestone-shaleand forming, or resting immediately on, the uppermost portion of

* Vol. i. pp. 61, 108, 111, \&c.

† These sections are unrivalled for extent and completeness. The vertical beds exposed to the coast-waves are worn by them in a manner to clear them of all detritus, and exhibit the whole series in a remarkably distinct manner.

$\ddagger$ 'Siluria,' 2nd ed. p. 300 . 
the Old Red Sandstone. These two formations, when Von Dechen's Map of the Rhenish Provinces was pnblished, were found to be parallel to the two highest divisions of the Devonian system on the Continent.

I may now proceed to a few details.

\section{§ 2. South Pembrokeshire.}

The best section, sheltered from the sonth-west winds, and accessible in part at all tides, is on the eastern side of Caldy Island. The Upper Old Red marls and sandstones, forming the southern horn of Drinkim Bay, end upwards in yellow conglomerates, and are covered by 400 feet of shale and limestome in a most variable series. At the very base are beds of shale with ordinary Carboniferons fossils, such as occur among the alternating shales and calcareous beds beneath the mass (nearly 2000 feet) of the Carboniferous Limestone, and in the base of that rock itself.

The Old Red Sandstone, therefore, at this locality is abruptly distinct from the overlying beds, in.colour, substance, and more especially in its destitution of fossils.

On the eastern side of the island, where the shales are best seen, I found the upper portion of the Old Red for some distance much softer than the beds below, almost destitute of cornstone, and chiefly consisting of sands and marls of bright colours, mixed with beds of pale conglomerate, which last is persistent through the island, forming reefs on either side, and stretching away far into South Pembrokeshire. This band of pale conglomerates is a good horizon; by taking advantage of it I was able to compare, bed by bed, the variable series of sandstones and marls below; and on the west side of the island, about 50 feet down in the Old Red series, to my great astonishment, a bed of Serpuloe occurred, in masses, like the S. filograna. I believe the species to be new, and call it Serpula advena (see figure, p. 496).

Crossing by boat to Skrinkle Bay, of which De la Beche and Ramsay have given detailed sections, the same beds are visible, even to minute details. It is needless therefore to describe the separate sections. Nearly every bed of calcareous shale, nodular or flat-bedded limestone, cherty sandstone, and oolitic limestone (which is very common) can be traced in the three sections. There is a special group of oolite-beds and grit near the base, a band of oolitic limestone two-thirds up, and between the two a remarkable series of thin cherty sandstone-bands, permeated thickly by the burrows of vorms. All of these subgroups are recognizable on the east and west of Caldy Island, at Skrinkle Bay, and, as will be seen afterwards, to the extreme point of Pembrokeshire.

These sections are all accessible by paths down the cliff, or better still by boat from Tenby.

At Skrinkle the upper 133 feet of Old Red Sandstone rests on some white sandstones, which are conspicuous at Caldy. The upper 37 feet of Old Red is, however, lost by an oblique fault, and this should be borne in mind in comparing the sections. 
The shale-series is remarkable for the quantity of broken and rolled Fish-remains. Psammodus or Helodus, Cladodus, and, more rarely, Orodus seem to be the chief cartilaginous Fish, with scales of Palceoniscus in plenty. Black rounded masses, which I cannot but regard as coprolitic, but in which my friend Mr. R. Smith can find no phosphates, contain bones of Fish, with Shells of Orthoceras, $\mathrm{Nu}$ cula, Cytheropsis, \&c. Sometimes rounded masses of this kind seem to have no organisms included in them. All are blackened. Again, rounded masses of the ordinary colour of the shale occur, enclosing Cytheropsis in myriads. Perhaps the whole may be water-worn, as Sir Henry De la Beche suggested* in the case of the very similar Bristol bone-beds. I do not know how to explain the blackening of the included Shells on that view of the case.

The number and size of the Worm-burrows, often 3 inches broad and many feet in length, form, perhaps, one of the most striking features in the Lower Limestone-shales. They are present, of small size but in great numbers, in the group of cherty rocks before mentioned, and which can be traced, about 70 or 80 feet from the base, throughout the whole of South Pembrokeshire. The action of the Worms bringing clayey matter into sandy beds, and vice versâ, gives great toughness to the rocks, and they resist the sea-action well.

Twenty miles to the westward the small bay of West Angle opens at the mouth of Milford Haven, and here a sharp faulted synclinal, in the middle of the bay, permits the whole section to be twice seen in the promontories and reefs on either side of the bay. The section has changed considerably from what is exhibited on the eastern coast, and nearly 150 feet + more shales are added to the upper part. In these shales a very perfect cleavage is established, fully justifying the term "Carboniferous slate" applied to this formation in Ireland by Sir R. Griffith $\ddagger$.

Sundry other changes are observable when this section is compared with that on the opposite sea-border. The Fish-beds are indeed present, the bands of oolite and grit agree remarkably in the lower part of the section, but the thick bands of limestone are replaced by nodular beds, which indicate a deficiency in the supply of lime. Again, there is a difference of importance near the base, inasmuch as the nodular limestone-bands there contain a vast quantity of a peculiar Bivalve, for which, as I cannot find a name, I have proposed the term Curtonotus (see Appendix, p. 494). It occurs in red limestone and grit, to the exclusion of all other fossils, in the bottom bands on the south side of the bay.

The yellow conglomerates have disappeared, but yellow and brown sandstone has taken their place; and there is a further remarkable change in the upper part of the Old Red Sandstone, to which I will direct particular attention.

* Mem. Geol, Surv. vol. i. p. 124.

t The upper part of the Skrinkle section measures 135 feet, that of Angle 322 feet. The conditions under which the beds were deposited were greatly different.

$\ddagger$ It is, however, the Lower Limestone-shale of Dr. Smith, as seen at Bristol and the Mendips. 
I may observe, that the section north and south of the bay is an unequal one, so far as the Upper Old Red is concerned, though marvellously exact in the overlying beds. On the northern horn of the bay the stacks and cliffs show a great many bands of conglomerate; on the south side scarcely any, the distance being barely a mile. Northward, the Old Red Sandstone is red sandstone and marl nearly to the top, intermixed only with a few subcalcareous bands and grey sandstone; but on the south side each of these intercalations becomes magnified, so to speak. The limestones are thicker and more frequent, and are crowded with fossils; the grey shales thicken out to the exclusion of the red marls ; grey sandstone is abundant; and the result is that, out of 120 feet, there is not above 25 feet of red shale in the upper portion of the Old Red Sandstone at this point. Then follow red, green, and grey beds, in the usual fashion, all the way to Freshwater*.

By this remarkable change in the mineral character we are prepared for a considerable change in the conditions of life. The solitary Serpula in the cliffs of Caldy had already indicated the neighbourhood of marine life. I found scattered specimens of the same Serpula here, about 70 feet below the top; but with it were a number of other forms, familiar to me only in North Devon, namely, Avicula Damnoniensis, in abundance; Cuculloea trapezium?; Rhynchonella laticosta; Bellerophon, three species, one identical with the $B$. bisulcatus of North Devon; with numerons undescribed forms of Pleurotomaria, Nucula, Sanguinolites, Modiola, Axinus, and Discina. In beds of shale associated with these are numerous linear Plants (observed first by Sir H. De la Beche), but not determinable; they extend their range into the underlying old Red $t$.

\section{§3. North Devonshire.}

This change in the mineral character, accompanied by the introduction of a marine fauna, conducts us somewhat less abruptly than would otherwise be the case to the calcareous and slaty sediments on the opposite coast of Devonshire. The red tint is, indeed, not wholly lost in North Devon, but is confined to narrow belts of the Devonian rocks.

I crossed from Combe Martin and nfracombe to Barnstaple, in more than one direction, and could find no red colour at all. A purple tint, however, stains the belt of slate-rocks (Morte Slates of Sedgwick and Murchison) which intervenes between the grey Middle Devonian slates of Ilfracombe and the Upper Devonian of Barnstaple and its neighbourhood. It is of these last that I must now say a little, the "Marwood beds" of the above authors being the uppermost strata of their Devonian system; and these, in their grey sand-

\footnotetext{
* It is worth while noting that the Old Red Sandstone at Freshwater, where it overlies the Silurian rocks, commences with a conglomerate of Silurian pebbles. We have, indeed, plenty of evidence that there is not in Pembrokeshire a continuous section from the Silurian to the Old Red Sandstone; and in all probability none but the upper division of the latter formation is present.

+ Mem. Geol. Surv. vol. i. p. 107.
} 
stones, calcareous layers, and argillaceous shales, are only (on a much larger scale) the limestone, shale, and sandstone we have left in South Pembrokeshire.

Neglecting then the purple Morte slates, which, being destitute of fossils, cannot yet be safely paralleled with any special division of the Old Red*, I may, however, say that they pass up by insensible gradations and loss of colour into the Marwood series.

In ascending order we have:-

1. Purple slates and sandstones of Morte Bay.

2. A band of pale, nearly white slate, with a few Bivalves.

3. A thick series of greenish-grey grits, with bands of $\mathrm{Cu}$ culloe and Avicula Damnoniensis, in abundance, and with much olive shale, in which a new Lingula occurs abundantly.

4. An alternating series of ealcareous sandstone, grey shales with thin nodular bands of limestone, and grey cleaved slate full of fossils, and many hundred feet thick. Avicula Dannoniensis and Rhynchonella laticosta, with numerous Lamellibranchiata, occur in the lower part; and Strophalosia caperata with Spirifer Barumensis throughout.

The series No. 4 is the upper part of the "Pilton group" of Phillips; and its aspect in the grand coast-section of Baggy Point and Croyde Bay is exactly like that assumed by the Carboniferous Slates of Pembrokeshire, as they lie, in the section before noticed, upon the fossiliferous beds of the Upper Old Red.

So like are the two sections, and so exactly does the succession appear to correspond, that my faith in fossil-evidence gave way, in 1854, before this apparent identity. The grey sandstone and intervening Plant-beds of Baggy are so like those of West Angle (on a larger scale), and the overlying calcareous and shaly series so like

Fig. 1.-Generalized Section in Pembrokeshire and North Ireland.

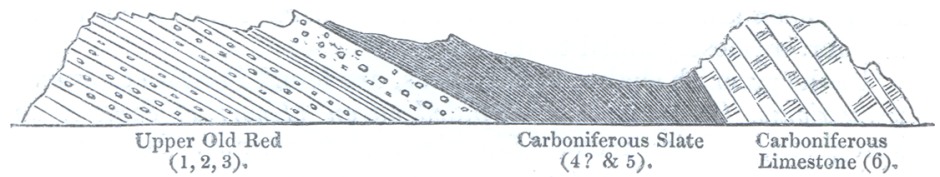

Fig. 2.-Generalized Section in Devonshire and South Irelard.

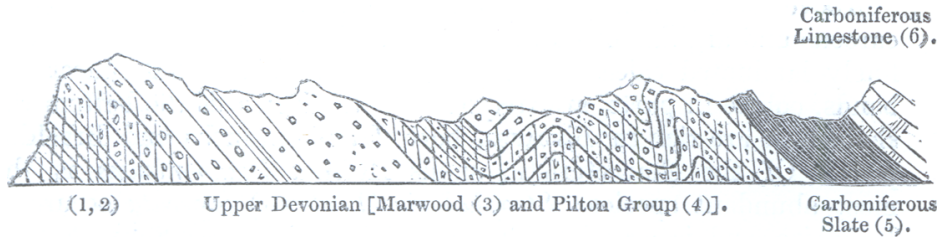

the bottom part of the Carboniferous Slate of Angle-having a very similar set of fossils and a few even identical,--that an older geologist

* Professor Jukes admits, as I do, these reddish-purple slates to be the equivalents of the Old Red of the South of Ireland, and in the same mineral condition. 
than myself mast be forgiven for having identified them. Sir $\mathbf{H}$. De la Beche was decided in his opinion of their being equivalents*. This view, however, is, I think, erroneous. The Upper Pilton group (No. 4) in the main represents a series unknown in Pembrokeshire (compare figs. 1\&2), or only represented by beds a few feet thick at the base of the true Carboniferous slate, while its lower portion and the whole of the Marwood group (No. 3) are certainly equivalent to the capping of the Old Red Sandstone. I hope I shall have the full concurrence of the Irish geologists in this last view; Mr. Jukes did all he could to persuade me, in South Ireland, of the intercalation of group 4. I eould not, however, disbelieve the North Devon section, but I had misinterpreted it.

I will now give a few of the chief fossil types, and glance at the necessary conclusions. The band of pale slate at its base is an excellent landmark for following the broken outline of the Marwood beds, from Baggy Point, where they are best exhibited, to eight or ten miles east of Barnstaple. The whole country is cut up by north and south faults, and by oblique faults not laid down on any of our maps, but they do not confuse the sequence much.

Either at Baggy Point, Braunton, Marwood, or Sloly quarries (the last locality being best known), the Marwood beds contain the following species:-

In the calcareous sandstones (often a brown limestone), Cuculloea trapezium and its varieties, C. Hardingii, Ctenodonta (Pullastra) antiqua, Avicula Damnoniensis, Edmondia, Sanguinolites, Axinus, Myacites, Modiola, and Orthonota of large and small undescribed species. Spirifer Verneuilii and S. laminosus? occur very rarely. The latter is a Carboniferous species, as also is Rhynchonella pleurodon, which is also met with in this bed, together with species of Natica, Platyschisma, Macrocheilus, Pleurotomaria, and Orthoceras with lateral siphon, chiefly, if not all, of undescribed species. Two species of Bellerophon are very common, one of them being either $B$. bisulcatus, Romer, or closely allied to it.

In the greenish shales, or silty beds, are found Bornia (Calamites) transitionis, Goppert, and Lepidodendron (Knorria) dichotomum, Haughton, and its roots. Lingula Mola †, sp. nov., is abundant, and Orthonota, or Myacites, rare. Discina also occurs, and Wormburrows are exceedingly abundant.

Above these sandstone-beds and olive shales commences the calcareous and argillaceous Pilton group. It is chiefly grey slate and finely laminated calcareous sandstone; but thin actual limestonebands, oolitic in parts, are frequent in it. Towards the bottom the shale-beds are rich in Bivalves, both Lamellibranchs and Brachiopods. Of the characteristic shells Avicula Damnoniensis is the most abundant species; Strophalosia (Leptaena) caperata occurs of large size, and is associated with Spirifer disjunctus, Sow., S. Barumensis, Sow., Productus prcelongus, Sow. (P. Christiani), Orthis in-

* Mem. Geol. Surv. pp. 133, 140, \&c.

+ Named after the Rev. F. Mules, of Muddiford, Barnstaple. Specimens are in the Museum of Practical Geology. 
terlineata, Sow., and Phacops latifrons, Bronn. But with them are present species of the new genus Curtonotus, of Ctenodonta, Modiola, Chonetes (small species), Bellerophon, and Aviculopecten (two or three species); also Encrinites of the genera Actinocrinus, Poteriocrinus, and Rhodocrinus, all abundant.

There are also black nodules, which contain phosphates disseminated in the shale along certain lines, and they are, I believe, droppings of Fish. They exactly resemble those in the very similar slate-series of Angle. There are crowds of Encrinites, not, so far as I can make out, of the same species, but exceedingly like those of the Angle Bay section.

There are Orthoceras and Nucula, a small spiral Euomphalus, smooth and black, and a minute Loxonema,-all of which closely represent analogous forms in the West Angle series. And there are the occasional pebble-beds (layers of flat shale-pebbles mixed with black nodules of various sizes), and the shells above mentioned, with Curtonotus, long meandering sand-lines, drifted patches with Shells in them, Annelide-burrows, \&c., all as at Angle.

Some of the species at Baggy Point are identical with those at Angle. I do not know how to distinguish the Rhynchonella from R. pleurodon. I find it exceedingly difficult sometimes to decide if the Spirifer be $S$. disjunctus or one of the varieties of S. attenuatus, \&c. But these doubtful cases (and there are not many of them) are overruled by the fact that the characteristic Shells are all of the Devonian type. The catalogue given (p. 480) scarcely contains a Carboniferous form; on the contrary, the peculiar species are abundant throughout.

As this is both the most complete and most accessible section, I will here say of it that the dip continues southwards, though with several minor faults and flexures, to Croyde Bay (where there is good accommodation for the geologist), and here the highest beds of the series are still full of Phacops latifrons; while the Chonetes and other shells, such as Athyris concentrica, are common. Spirifer laminosus, a Carboniferous fossil, occurs here among them, but rarely.

The section on the south side of Croyde Bay is only a repetition of that on the north, and the cliffs along the coast to Saunton show only the same fossil forms.

Exactly similar sections are obtainable along the nfracombe road from Braunton, along the course of the Knowlwater to Marwood, and again from Barnstaple. On this last section a few notes may suffice. I had the advantage here of the great local knowledge of the Rev. F. Mules, who has produced a MS. map of the range of the several subdivisions of the rocks of North Devon. It gives the general course of these formations with accuracy, from Morte Bay to Exmoor, beyond which the Marwood beds have not yet been traced. I did not myself go quite so far east.

The road-section from Muddiford to Barnstaple shows a perfect sequence from the purple slates, through the white band, to a welldeveloped Marwood group. The great quarries at Sloly are those best known as containing the Lepidodendra, Calamites, and other Plant-fragments first described by Professor Sedgwick. I have the 
measurements of all the beds, and I find that Lingula oceurs in great quantities in the olive shales, while the calcareous sandstones are full of Cuculloea, Bellerophon, Orthoceras, \&c. The whole must have been accumulated in a very shallow sea.

Thence southward, undulating beds of slate with many sandstonebands contain all the fossils of the Pilton group. Top Orchard quarry, near Pilton, is a favourite locality. In beds below this, and very near the base of the group, I found a single specimen of Curtonotus, which is somewhat important, inasmuch as this genus, both in Pembrokeshire and in South Ireland, belongs only to the beds which underlie the true Carboniferous slate. Spirifer disjunctus, Productus Christiani, i. e. proelongus, Avicula subradiata, and Athyris concentrica are still the common fossils.

But nearer Barnstaple these Pilton beds begin to trough small patches of a barren softer slate, which is only seen wel! developed south of Pilton, and occupying the lower ground east and west of Barnstaple. Another anticlinal roll throws in a trough of it about Ashford and Heanton Punchardon, and it is fossiliferous on Ashford Strand. South of the river it may be seen along the course of the railway, skirting the marshy ground, and there is a good section of it at the railway-station.

It is extremely difficult to say precisely where the Pilton group ends and this group of shales begins; but the absence of sandstonebands and the presence of only Carboniferous species show sufficiently the reality of the change. Strophalosia caperata, var. membranacea, is occasionally present, but not the ordinary variety. It is associated with Spirifer laminosus, S. cuspidatus, Streptorhynchus crenistria, Chonetes Hardrensis, Athyris Roissyi, Bellerophon decussatus, Productus costatus, P. Martini, Orthis Michelini, Venus parallela, Phillips, Spirifer ovalis (small), S. bisulcatus, Phillipsia seminifera, and many others. But these are enough to show that we have passed from the sandy Pilton group to the true Carboniferous Slate. The Encrinites are exceedingly common; but those stems I have been able to compare with Pilton species are not identical, while all the peculiar Pilton species are quite absent. Yet the general aspect of the Encrinites, Fenestella, striated Spiriferi, Chonetes, \&c., is so much that of the Pilton group just underlying, that it was only by great good fortune I made out the troughs of this newer formation, lying among the contorted beds of the Pilton group.

South of Barnstaple we are indeed fairly in the Carboniferous series. Along the course of the Fremington Pill I found, in 1854, shaly beds overlying these, still with Mountain-limestone fossils. The Productus Cora, or rather $P$. Scotica*, as it ought to be called, is a fossil not yet detected eten so low as the Limestone-shale. But how far upward the Mountain-limestone extends until it is capped by the Millstone-grit of Coddon Hill it would be out of my province to discuss here. It is more to the purpose to mention briefly the

* Sowerby's type-specimens of $P$. Scotica are identical with the shell D'Orbigny afterwards called $P$. Cora, and $M^{\prime}$ Coy $P$. corrugata. 
result of a short visit to the southern side of the culm-trough, in the autumn of 1857. The Torquay section was briefly examined, and its correspondence with that of the Spirifer-sandstone group of the Rhine, as given in 'Siluria,' easily perceived.

The fossils of the ordinary Plymouth limestones, of all colours, are so well known that no time need be spent in proving them to be the equivalents of the Eifel limestone, or of the Combe Martin limestones of North Devon. Unfortunately the special object on which I was sent did not permit me to examine the Newton Bushel section*; but on crossing the Devonian slates from Plymouth, by Tavistock, to Launceston, I found everywhere the same silvery slate which must be familiar to every geologist who has visited Ilfracombe. Nor was I then aware of the importance of identifying the red band of the Morte slates with the beds about Launceston and Petherwin; though I now believe them to be equivalents-a point of no little importance in the geology of Devon and Cornwall; for, in a tolerably careful survey of the Launceston beds, I fully convinced myself (and, on my return, Sir Roderick Murchison) that the Petherwin limestone-group did not represent the Barnstaple series, as had been formerly supposed, but that it was a lower band in the Devonian series $\uparrow$. The reason for this determination will appear by comparing the following list of fossils, all of which came from the Landlake and Petherwin quarries, with those above named from the "Marwood group."

\section{List of the Petherwin and Landlake Fossils (Upper Devonian).}

Petraia Celtica.

Amplexus tortuosus.

Cyathophyllum cæspitosum.

Fenestella laxa.

- antiqua.

Sanguinolaria? sulcata.

Ctenodonta (Pullastra) elliptica.

Orthonota (Cypricardia) semisulcata.

Axinus (Cypricardia) deltoideus.

Aviculopecten granulosus.

A transversus.

- alternatus.

- arachnoideus.
Pterinea ventricosa.

A vicula subradiata. exarata.

Cardiola retrostriata (Cardium palmatum).

Strophalosia caperata, rare.

- membranacea, more frequent.

- subaculeata (Leptæna laxispina,

L. fragaria, \&c.), abundant.

Orthis interlineata.

resupinata.

Streptorhynchus crenistria.

Spirifer protensus.

* I have lately seen it, for a single day, in company with Mr. W. Vicary, of Exeter. It is clear enough that there is an Upper as well as a Middle Devonian series in this place, the lower limestones of Bradley Woods being quite different from the higher, close to the town, and containing different fossils. The Upper or Clymenia-limestones must have existed close by, as pebbles from them, containing the Clymenice, are abundant at Teignmouth (Shaldon).

$\uparrow$ That this determination is not without its value will appear on comparing the statements made to the above effect in 'Siluria,' p. 300, with those in the Preface to the 2nd Fasciculus of Prof. Sedgwick's Cambridge work, 1852, or more lately in the excellent Synoptical Table by Professor King, of Galway, in which these authors place the Petherwin Slates with Clymenia (the true Upper Devonian of the Continent) above the Marwood or Coomhola group. In the Continental sections one or other of these is frequently absent, the true reason for which will be apparent as we proceed. 
Spirifer Urii (S. unguiculus).

Spineatus?
Vermeuilii.
Barumensis? *
disjunctus, including S.giganteus.
grandærus.
bisuleatus.
Atrypa desquamata $t$.
Rhynchonella pleurodon.
subdentata.
rhomboidea.
Eugnus?
Euomphalus serpens.
Natica nexicosta.
Pleurotomaria cancellata.
antitorquata.
aspera.
Loxonema sinuosa?
nexilis.

Bellerophon (trilobatus?), probably $\boldsymbol{B}$. bisulcatus, Roem.

Orthoceras cinctum.

laterale.

- striatulum.

- striatum, $\boldsymbol{M} \cdot \mathrm{Coy}$.

- fusiforme.

Cyrtoceras rusticum.

Nautilus megasipho.

Goniatites insignis.

bisulcatus.

- biferus.

Clymenia lævigata.

- striata.

- - linearis.

- fasciata.

- sagittalis.

- plurisepta.

Phacops (Calymene) granulatus.

This list, it may be observed, differs in almost every point from the Barnstaple list, and the Petherwin beds were probably deposited in deeper water. It is true that several of the characteristic fossils are the same in both series; but there is an entire absence in the Pilton or Barnstaple series of the Clymenice and Goniatites, so characteristic of Upper Devonian strata on the Continent, and also of the Phacops granulatus. I have taken the list as it stands in my note-books, adding to it the species quoted by Professor Phillips, for which we are chiefly indebted to the researches of Mr. Pattison. Mr. Lee, of Caerleon, contributed some good materials.

It will be seen, too, that this list fails in two or three important points to tally with that of the fossils from the Barnstaple series. Instead of the large Phacops latifrons, we have the small P. granulatus; Spirifer Barumensis is, I believe, quite absent; Productus proelongus is not found there; and Strophalosia subaculeata takes the place, as an abundant species, which $S$. caperata occupies at Barnstaple. Much of this change may be due to a different depth of water for the deposit; but it cannot be wholly so; and I should look for the equivalent of the Petherwin beds, which are exactly the "Clymenien-Kalk" of the Prussian geologists, in the red slates of Morte Bay.

It was in vain to search for the Pilton group along the borders of the Culm-measures, which, contrary to expectation, I found to be unconformable to the Devonian beds, at least near Launceston. And in its lowest beds, very black shales with much chert in them are the usual state of things in the Culm-messures.

The shales or slates in which the Devonian limestones of Petherwin occur are very much like, in a general sense, those of Ilfracombethat is, pale grey slate, with no sandstone-beds, and bearing all the marks of deep-sea accumulation.

* I am not sure of this species.

+ This I think doubtful, but it is important to notico it. It may be Atrypa reticularis. 
Further north, in the midst of the undulating trough of Culmmeasures, a locality called Yealm Bridge, north of Launceston, has long been known as a fossiliferous place. It is a sharp and faulted anticlinal of hard slate-rocks, about a mile or a mile and a half in diameter; and Mr. Pattison, who knows the spot well, told me I should find Petraia and Phacops latifrons there. This then would identify the rock with the Barnstaple series, of which we otherwise have no trace on the south edge of the Culm district. I found this statement strictly correct; and the list of fossils, imperfect as it must be (being the result of only two days' examination), is yet a sufficient index of the true geological position. The dip being northwards, and the Culm unconformable, it was only to be expected that we should find higher beds in an exposure to the northward; and I believe this small inlier (to adopt a new and proper phrase, invented by Mr. Drew) is one of the best proofs we could have that the Barnstaple or Pilton group overlies the Petherwin group.

\section{\$ 4. Somersetshire, Gloucestershire, and Shropshire.}

Before passing over to the South of Ireland, it will be well to notice the general character of the parallel sections further to the north-east, namely, at Dean Forest, Bristol, and the Mendips; and to call attention to the newly described section of the Clee Hills, as given in Mr. Roberts's and Professor Morris's account in the Society's Journal*. This must necessarily be brief, and it may be at once stated that all these seotions conform nearly to the northern type, or that of Tenby above described. In all, the thick limestones are succeeded, in the downward section, by arenaceous shales and thin limestone-beds, and these by sandy beds, grey, and finally yellow as they pass into the red marls and sandstones of the Upper Old Red.

In Dean Forest Mr. James givest, below the alternating shaleseries, the following beds :-

Carboniferous.. $\left\{\begin{array}{l}\text { Arenaceous shales. } \\ \text { Coarse yellow sandstone containing Shells. }\end{array}\right.$

Upper Old Red. $\left\{\begin{array}{l}\text { Red marl. } \\ \text { Red marl with yellow sandstone. } \\ \text { Coarse yellow sandstone and whitish shale, full of } \\ \text { Plants. } \\ \text { Green shale and sandstone. } \\ \text { Red marl. } \\ \text { Thick yellow sandstone, with whitish shale. }\end{array}\right.$

Red marl.

Greenish and grey sandstones and shale, very micaceous, \&c.

And so on until the whitish and grey sandstones cease to appear among the red marls. We must, by comparison with the Tenby sections, draw the divisional line as above.

In the Lower Purlieu section, in the same district, the limestones,

* Vol. sviii. p. 94. + Geol. Surv., Vertical Section No. 12. 
mixed with shale, come close down upon the yellow sandstones, as is the case at Clydach in Monmouthshire in even a more striking way*.

The well-known Clifton section also gives the same results, with the great advantage of being all visible along the Aron. Mr. D. H. Williams givest, below the thick alternating series of shales and limestone, crowded from top to bottom, as I have myself seen, with the same Mountain-limestone species as those common at Tenby,

Grey shale and red marl (thin limestones).

Light quartzose sandstone and conglomerates.

Red and claret-coloured marls and sandstones.

Light grey and brown sandstones and shales.

Red marls and light-grey sandstones, \&c. \&c.

I must by no means omit to notice the careful section of the Farlow beds $\div$ by Messrs. Roberts and Morris. In this compact paper, the passage upward from

1. Red sandstone, with cornstone, to

2. Yellow sandstone and conglomerate, containing Holoptychius giganteus, Pterichthys macrocephalus, and a larger species, and then to

3. Grey oolitic limestones, bearing Fish, or Crinoids, or Brachiopods in the several bands, and these interstratified again with clays of various colour,

is completely in accordance with the Pembroke sections. The Brachiopods are mostly identical with those from Tenby. Spirifer cuspidatus, and the varieties which seem to connect this species with S. distans, Sow., together with Athyris, Rhynchonella, and other fossils, completely recall to mind the Tenby sections.

The Fish too, though far more numerous and better preserved, are in the main identical. Orodus, Psammodus, Helodus, and Cladodus, among them, are excellent types for the Lower Limestoneshales.

But the measured thickness of this section gives us no idea of the masses to be seen in Pembrokeshire; and we have only the general accordance- of red sandstones surmounted by yellow grits full of characteristic Opper Devonian types- to assure us that the Upper old Red is here, as in the sections above described, gradually losing its colour before being overlain by the deeper-water sediments of the Carboniferous series.

In the Mendips a valuable section by Mr. D. H. Williams $\$$ shows the same alternations of impure limestone and shale, at the base interstratified, as at Caldy Island, with red limestones and oolitio bands; and a thick series of brown calcareous sandstones which can be exactly paralleled with Nos. 77 to 80 of the Skrinkle Bay section $\|$.

Then a few alternations of red shale and cherty limestone at the base conduct us to hard light-grey sandstones, which here form the

\footnotetext{
* Mr. Rees's Section, Geol. Surv., Vertical Section No. 12.

+ Geol. Surv., Vertical Sections Nos. 11 \& 12.

\$ Quart. Journ. Geol. Soc. vol. xviii. p. 95 .

$\$$ Geol. Surv., Vertical Section No. 12.

|| Ibid. No, 12.
} 
uppermost part of the Old Red, as they do in the sections just quoted. This is perhaps the nearest approach to the North Devon type that any of the sections on the parallel of the Bristol Channel present.

These light-grey sandstones and the intervening grey and greenish shales should be well searched. They are sure to contain the characteristic Knorria dichotoma; for this (or analogous Plants) was found by Earl Ducie in the Tortworth grits. And it would be a great corroboration of this view if some beds of the Avicula Damnoniensis could be found among them, as in the West Pembroke section.

\section{§5. South Ireland.}

While we wait for a memoir on the Irish Upper Devonians, I cannot do better than give a short abstract of the paper by Mr. J. Beete Jukes and myself, published in the 'Journal of the Geological Society of Dublin,' 1855 , vol. vii. p. 63.

First, we found it impossible to separate the so-called Yellow Sandstone of the South of Ireland from the Old Red, for the good and sufficient reason that it is, as in all the other sections, the upper part of that formation itself, losing its colour preparatory to the in troduction of the Carboniferous series. [The Yellow Sandstone of the North of Ireland is a different thing; as in Scotland it is there the base of the Carboniferous Limestone, and contains Carboniferous fossils only.] Both in the Yellow Sandstone and the red and green beds below we found the Knorria and its roots (Filicites dichotoma, Haughton). In more productive beds in Kilkenny and near Cork Prof. E. Forbes had already found the Anodon? Jukesii, which is probably a Modiola. Stigmaria and Lepidodendron occurred here, but no decided traces of Sigillaria, nor do I believe there are any instances of this genus occurring below the lowest Carboniferous beds.

Next, the Carboniferous Slate, which overlies the Yellow Sandstone, is very thin towards the east-that is, in Kilkenny, Waterford, and Wexford (the fine section at the Hook, Wexford, is the best worth study); but towards the west it thickens out, and from Cork to Bantry is interstratified at its base with grits, which form, near Glengariff, a group 3000 feet thick, and which were termed by us, as they had been previously by Mr. Jukes and the Irish Survey, "Coomhola Grits."

If a line be drawn from Kenmare through Macroom and Cork, thence south of Youghal to the Bristol Channel, it will coincide with the boundary between the northern or Herefordshire type of the Old Red Sandstone and Carboniferous Shale, without the intervention of the Coomhola Grits, and the southern or Devonian type as seen at Bantry, Kinsale, and all through Devonshire. It will define also the northern limit of the "Coomhola Grits." And, lastly, it is the boundary-line between the coarse shallow-water deposits of the Old Red Sandstone, with pebble-beds and Plants, and the more open-sea Devonian deposits, of thicker mass, finer grain, and lighter colour, full of marine Shells and Corals. The boundary is not an arbitrary one, but appears to have been a line of coast, or of shallow water, 
during the period of the deposition of the limestone-shale, as well as the uppermost beds of the Devonian series.

These grits, we observed, differed little from the Devonian grits below them, except in being chiefly grey, and having intercalated beds of dark grey, instead of greenish, shales. The partings of black or dark-grey shale constitute the only mineral character we could find to separate the two series.

The fossils of the Carboniferous Slates and Coomhola Series are as follows:-

\section{Carboniferous Slate.}

A mong a host of others occur Fenestella plebeia, Actinocrinus, Platycrinus, Poteriocrinus, and Rhodocrinus, which I think identical with the Carboniferous forms. With them, however, were in abundance Spirifer cuspidatus, a Carboniferous form, with $S$. disjunctus? (I believe this to be the wide form of $S$. bisulcatus, so common in all the Pembroke sections). In addition were Orthis Michelini, Streptorhynchus crenistria, Athyris squamosa, Productus, sp., Rhynchonelia pleurodon (abundant), Orthoceras, Nucula, and, lastly, the Modiola Macadami, Portlock,-a shell abundant in Lower Carboniferous beds. Annelide-trails and -burrows were abundant in all the beds, as they are also in the underlying Coomhola Grits.

\section{Coomhola Series.}

In the western part of Cork, and notably at Dunworley Bay, Dirk Bay, Skibbereen, and Glengariff, we have Encrinites of the same genera as above, but several of them apparently of different species from those of the Carboniferous Iimestone. Rhynchonella pleurodon, Spirifer cuspidatus? (doubtful), S. disjunctus (S. Verneuilii, Murch.); many undescribed bivalves of the genera Modiola, Ctenodonta (Nucula), Cuculloea, Axinus, Avicula, Aviculopecten, and a new genus for which I proposed the name Curtonotus; Bellerophon, with rounded, keeled, and trilobate dorsal edges, as in North Devon; Cucullcea of several species, and C. trapezium; Lingula, new large species; Rhynchonella pleurodon and $R$. laticosta?; and, lastly, the most common Shell and Plant, Avicula Damnoniensis and Knorria dichotoma in every shale-bed.

The conclusions we arrived at were:-

1. That in South Ireland the Yellow Sandstone was the upper part of the Old Red.

2. The Carboniferous Slate, whether well or thinly developed, contains in its upper part the ordinary Carboniferous types.

3. A local but considerable group intervenes, physically more connected with the Carboniferous, but distinct as to fossils. It has the same Plants as the Upper Devonian'(that is, Upper Old Red), some few Shells of the Carboniferous Limestone, and numerous Bivalves peculiar to itself. This group is the equivalent of the Marwood sandstones*.

* In part only : as I have above shown (p. 480), it is the true equivalent of the Upper Pilton group.-J. W. S. 
4. In our postscript we inclined to the view that No. 3 was a decidedly Carboniferous group ; but this was owing to the mistaken notion that the Pilton or Upper Marwood group was the equivalent of the Carboniferous slate,-a statement made on my own authority, as above noticed. For all else in this memoir, except the supposed identification of the Spirifer disjunctus in the Carboniferous Slate, and of S. cuspidatus (which I now believe to include S. Barumensis) in the Coomhola Grit, I am willing to be equally responsible with $\mathrm{Mr}$. Jukes.

\section{§ 6. Foreign Equivalents.}

On these I do not intend to say much, having never seen the French and Belgian Devonian rocks. But the broad and general view of them given in the second edition of 'Siluria,' together with Messrs. Sharpe and Godwin-Austen's papers in our own Journal, surely entitle us to attempt the parallel, which I hope personal observation will enable me one day to verify.

In the last edition of 'Siluria' the three or, rather, four subdivisions of the Old Red Sandstone are thus given in ascending order :-

1. Tilestones or " Passage $\left\{\begin{array}{c}\text { This term has given rise to much con- } \\ \text { fusion, and the beds would be much }\end{array}\right.$ beds." better called "Ledbury Shales;" I, therefore, propose this term for them.

2. Lower Devonian, "CoblentzSandstone,"Lower Cornstone group of the Old Red.

Characterized by Cephalaspis, Pteraspis, Pterygotus, \&c., as well as by peculiar Shells.

3. Middle Devonian, Eifel and Plymouth Limestones, Caithness Flags.

4. Upper Devonian, Yellow and Red Sandstone, Cypridina-schist, Flinz and Kramenzel-Stein, Petherwin Group.

Coccosteus, Asterolepis, Dipterus, Calceola, Stringocephalus.

Holoptychius, Glyptopomus, Cucullaea trapezium, Avicula Damnoniensis, Spirifer disjunctus, Athyris concentrica, Strophalosia subaculeata, Cardium palmatum, Clymenio, Phacops granulatus.

Comparing with the above series the last revision of the Devonian Geology of the Rhenish Provinces, as given in the Map of Von Dechen and his associates, we find the following:-

1. Ardennes Schiefer, Co- These are represented truly by our blentz-Schichten (or Linton and Fowey groups, in North

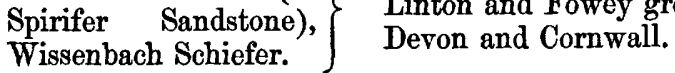

2. Lenne-Schiefer, Eifel- $\}$ Plymouth and Combe-Martin LimeKalk.

3. Cypridinen-Schiefer, including the Goniatiteshales, Flinz, and Kra- $>$ Petherwin Group in every detail. menzel-Stein with $C l y$ menice.

VOL, XIX. -PART I. 
4. Verneuilii-Schiefer, Ar- Marwood (and Pilton?) Group, with gillaceous Sandstone. $\}$ exactly the same fossils.

These Verneuilii-Schiefer (a bad name for a group already named by Sedgwick and Murchison) come up in long parallel folds near Aix-la-Chapelle and rest on the Eifel-Kalk, without the intervention (at this place) of the Cypridina-Schist, and are themselves covered by the Kohlenkalk or Mountain Limestone. This fact is valuable, as indicating what we have as yet failed to detect in North Devonan unconformity between the Marwood group and the other members of the Devonian formation*.

In the Bas Boulonnais, Sir Roderick Murchison described, in 1840 , some of the Devonian species, but failed to make out that the whole series was only the uppermost portion of that formation; nor was Mr. Godwin-Austen, in $1853+$, completely set free from the notion of older Devonian rocks being present, as Delanoue and others had determined.

But Mr. Austen's paper gives all the necessary elements for correcting this view; the stratigraphy is clear, and the lists of fossils complete. Below the Mountain Limestone he found a band of shale (Le Hure, Ferques, \&c.), which he passes over without much comment, but which must either be the Limestone-shale or the Pilton group, and his paper conducts us at once to

The Yellow Sandstone group = "Grès à Cnio" of Rozet [Psammite de Ludlow, of the Boulogne Meeting $\ddagger$ ], Landrethun to Ferques, 25 feet thick (Bois de Beanlieu, \&c.), meeting the Coal-measures (Dufrénoy), Marwood Sandstone (Austen).

There can be no doubt of the age of this sandstone. Cucullcea Hardingii, C. trapezium, Bellerophon subglobatus, \&c., tell the story at once, and leave us free to consider the strata below them.

If the Boulogne formation were anything like the same in development as our North Devon series, the thickness of 25 feet of sandstone would give us a mere capping for the great Marwood series; accordingly we find, in descending order,

$\left.\begin{array}{l}\text { Bright red shales and clays. } \\ \text { Dark grey shales } . \ldots \ldots \ldots\end{array}\right\}$ Château de Fiennes.

Ferques limestone.-Near Malaise, Bois de Beaulieu, and to the

Chateau de Fiennes. Great abundance of Spirifer disjunctus.

A selected list of the fossils of this limestone gives us the true Pilton group. We have Athyris concentrica, Rhynchonella pleurodon, Spirifer Bouchardi, S. disjunctus, Strophalosia caperata (S. scabriculus, Sharpe), and Phacops latifrons ( $P$. Latreillii). With these, however, are a few which are more characteristic of the Newton-Bushel limestones than the Barnstaple group, namely, Atrypa reticularis,

* Unconformity to the largest extent has long been known between the Upper and Lower Old Red in South-west Ireland. Sir R. Griffith described it; Sir R.I. Murchison, Mr. Jukes, the Members of the Geological Survey of Ireland, and myself saw it in 1856; and since then Mr. Geikie has described the same thing as occurring in Scotland. See Quart. Journ. Geol. Soc. vol. xvi. p. 312.

† Quart. Journ. Geol. Soc. vol. ix. p. 231, \&c.

$\ddagger$ Bulletin de la Société Géologique de France, vol. x. p. 404, 1840. 
Terebratula hastata, Spirifer heteroclytus? (S. subconicus), Strophomena Dutertrii, and Strophalosia subaculeata; also Favosites polymorpha, Cyathophyllum, and other Corals. Red shale, again, and dolomitic limestone lead down to the Blacourt Limestone (=Limestone of La Cédule, \&c.), which is worked in part for iron-ores. Still we have the same fossils, with some omissions and additions, and then a series of shales, which is followed by compact micaceous sandstone with Ferns*, Calamites (probably Bornia transitionis), \&c., with some of the above fossils. There is nothing in the whole section to indicate that we have reached $A$ lower horizon than that of the Marwood beds. Mr. Austen's comparison of them with the Ogwell, Plymouth, and linton groups is the only flaw in an admirable paper.

In Mr. Sharpe's paper in the same volume of our Journal t, an attempt is made to compare the Belgian series with our British rocks. Generally speaking, it comes to the same results as those given in 'Siluria' above quoted.

But the lower part of M. Dumont's "Système Condrusien" evidently includes the Barnstaple (and Petherwin?) group, resting as this does upon the Eifel or Middle Devonian series.

For the present it will be sufficient to indicate that the "Système Condrusien" may be divided thus :--

$$
\begin{aligned}
& \text { Upper }=\text { Carboniferous Limestone. } \\
& \text { Lower }=\text { Barnstaple or Pilton group. }
\end{aligned}
$$

The grey micaceous sandstones and flags of the lower division certainly point to the same horizon as the sandstones, shales, \&c., of the Boulonnais, and M. Gosselet's important paper $\neq$ only confirms this idea.

I take advantage of this opportunity (referring to the abstract by Mr. Pattison in the Journal for November 1861, vol. xvii. part 2.p.27) to enumerate the chief divisions of the series as given by $\mathbf{M}$. Gosselet. In descending order, his numbers are:-

$\left.\begin{array}{l}\text { Nos. 1. } \\ \text { 2. } \\ \text { 3. }\end{array}\right\}$ Coal and Carboniferous Limestone. 4. Psammites de Condros $=\left\{\begin{array}{l}\text { Marwood beds; containing Pha- } \\ \text { cops latifrons, Athyris concen- } \\ \text { trica, Spirifer Verneuilii, and } \\ \text { Strophalosia scabriculus (pro- } \\ \text { bably S. caperata). }\end{array}\right.$
5. Slates of Famenne $=\left\{\begin{array}{l}\text { Pushel limestone; containing } \\ \text { Rhynchonella cuboides, Spirifer }\end{array}\right.$
6. Givet limestone = Plymouth and Ogwell.
7. Calceola slate =Limestone-shale (Chircombe, \&c.).

* These fossils should be examined carefully. In all probability the Fern is Adiantites Hibernicus. Moreover, the so-called Graptolites from Caffiers have been determined to be leaf-stems or -stalks. Here we have all the analogies of the Marwood group.

† Vol. ix. p. 18. $\quad$ † Bull. Soc. Géol. de France, $2^{\text {me }}$ sér. vol. xviii. p. 18.

$\S$ The author specially remarks the absence of the Clymenia; but though this 
Nos. $8,9,10$, the remaining Devonian groups, are not necessary tn our purpose. But it is worthy of remark that the fossils quoted by $\mathbf{M}$. Gosselet as having been found by M. Hébert in the Burnot conglomerate are Marwood species (Cucullcea Hardingii, Productus? Murehisonianus, \&c.), and must have been obtained from other and higher beds.

It would appear, from all that has been published regarding the Upper Devonian beds of Saxony, the Hartz, Nassau, and Westphalia, that the Marwood beds are absent in these districts, - the Carboniferous Limestone resting at once on the Clymenia-limestone, or Petherwin group.

In the Rhenish provinces, in Belgium, and in the north-west of France, on the contrary, the Marwood group is present. And this variety in the distribution adds strength to the inference already drawn on other grounds, that the Marwood group is unconformable to the other members of the Devonian. The Carboniferous Slate is, as we have seen, only here and there dereloped to its full extent; and as we know that the Mountain Limestone itself is universal orer the greater part of Europe, and has besides a much wider extension, the reasonable inference would be that, after the filling-up of the sea-bed towards the close of the Devonian period, a continued subsidence took place, which allowed the older beds to be gradually covered up successively, first by the Marwood and Pilton group, then by the Carboniferous Slate or Lower Limestone-shale (the terms are convertible), and lastly by the thick masses of the Mountain Limestone itself, which we know in many cases orerlaps the whole Devonian series and rests upon the Silurian slates.

I should scarcely have referred to the North-American area but for the purpose of directing attention to a rery interesting point, confirmatory of all that has been said above regarding the age of the uppermost Devonian - the "Chemung group" of the New York series.

Of this group Professor Hall has given sufficient details in his 'Geology of the Fourth District' to enable us to see that its fossils, as a whole, agree well with the Petherwin or Upper Devonian group: It includes several fossils with which we are familiar. Amongst them, Phacops nupera, Hall (P. bufo, var.); Aviculopecten, a great many species; Orthis interlineata; Spirifer disjunctus, and many others, including S. Urii (S. unguiculus); Atrypa reticularis, and many varieties of this variable shell, as in our own Newton-Bushel limestones, e. g. A. dumosa, A. hystrix, A. tenuilineata, \&c.; Petraia, Ceriopora, \&c.; also Avicula Damnoniensis in plenty. This group of species might be easily referred to the Barnstaple group, but it is more agreeable with the whole of the facts to consider it the equivalent of the Petherwin or Clymenia-group, and the fossils are rather in favour of this view. Moreover, Professor Hall lays

omission is of importance, and may render it possible for No. 5 to be a lower member of the Barnstaple or Pilton group, this is unlikely, as Cardium palmatum is a characteristic Petherwin species, and rarely. if ever, occurs in the Marwood beds. 
1863.]

stress on its union, as a formation, with the rest of the New York series-the Portage, Hamilton, and other groups, which represent the mass of the Devonian. It is covered (unconformably?) by the Catskill conglomerate, which there can be no doubt represents our own Upper Old Red, and therefore the Marwood series inclusively.

\section{§ 7. General Conclusions.}

If I have thus established clearly, by position, by intercalation of marine beds with the red sandstone, and by fossils, the identity of the uppermost Devonian or Marwood group with the Upper Old Red (I must omit for the present the Petherwin group, which is also probably, but not certainly, included in this upper division), it remains to be seen whether the same great clue-the fossil evidencewill suffice to give us the long-wished-for identification of the Middle and Lower Devonian with the Middle and Lower Old Red Sandstone. It is not difficult of proof.

I hold that the masterly suggestion of Sir R. I. Murchison, that the Caithness Flags, full of Coccosteus, Pterichthys, and a dozen other genera, belong to the Middle, and that the Cephalaspis-beds of Scotland belong to the Lower Division of the Old Red, is the greatest advance made of late years in the classification of the British Devonian rocks.

Without this clue we were in a sea of difficulties and contradictions. But, following it out, the whole of the Old Red Sandstone subdivisions fall into their proper places, and can be correlated accurately with the Continental equivalents*.

Thus, in Russia, the Eifel, and the Hartz, Coccosteus, the characteristic Fish of the Middle Old Red beds, is found associated with the fossils of the Eifel or Middle Devonian limestone. In Russia, Sir Roderick Murchison informs me, they have been found by his friends in the same slab. The identity of this part of the two formations is thus proved, and need not further be discussed.

But what of the Cephalaspis-beds or Lowest Old Red? And how are we to identify them with the Lowest Devonian, the Coblentzian or Rhenane series?

Professor Ferd. Rœmer + and Professor Huxley $\ddagger$ have unexpectedly answered this question for us. The former obtained a fossil which he supposed to be a naked Cephalopod, allied to the Sepia, and which he described as Archooteuthis Dunensis in the 'Palæontographica' and the 'Jahrbuch.' It came from the Lower or Coblentzian rocks of Daun. Afterwards it was again obtained from Wassenach, on the Laacher-see, Lower Eifel. There is no doubt whatever that

* While these pages are writing, Sir Roderick has received specimens, obtained by Mr. C. Peach, from the beds which rise out from under the Caithness flags, at Ulbster Wick. They prove to contain specimens of the Pterygotustype, and are most satisfactory as proving the succession to be what was before indicated. See Prof. Ramsay's Anniversary Address to the Geological Society, Quart. Journ. Geol. Soc. vol. xix. p. xlv. 1863.

+ Palæontographica, vol. iv. p. 72 ; Jeonhard and Bronn's Jahrb. 1858, p. 55.

$\ddagger$ Quart. Journ. Gool. Soc. rol. xvii. p. 163. 
Professor Huxley is right in referring this fossil to the genus Pteraspis - than which Ganoid Fish, abnormal though it be, there is no more characteristic fossil of the Lower Cornstones of the Old Red Sandstone. The Lower Devonian is therefore the equivalent of the Lower Old Red Sandstone.

There remain only the "Tilestones," or "Ledbury Shales," which contain a different fauna from all these, but unequirocally (as I believe) Lowest Deronian. But as these should form the subject of a separate memoir, I will not trench upon that ground at present.

\section{§8. Appendix. \\ Cortonotus, gen. nov.}

It is nccessary here to give the characters of a genus of Bivalves, often quoted in the preceding pages, and which has long been known in our lists of fossils without having been sufficiently illustrated.

$\mathrm{I}$ believe I proposed the name in the joint memoir by Mr. Jukes and myself in 1855. The genus is intended to include a number of oval thick-shelled bivalves related to Myophoria and Axinus, but distinct at a glance by the general rounded form, and technically by the simple, not divided, central teeth of the hinge.

The genus is characteristic of the Pilton group throughout, occurring at its extreme attenuated end, or immediately above it, in Pembrokeshire, and abundant throughout the Coomhola grits of South Ireland, while it occurs, though rarely, in the Barnstaple slates.

Some six or eight species are recognizable; some of which are mentioned in the Explanations of Sheets 197, 198 of the Irish Survey, pp. 10 et seq.; and one is figured in Professor Jukes's 'Manual,' 2nd edit. p. 508, fig. $14 f$.

The following names are used in the Explanatory Sheets for the Irish Survey, Sheets 197, 198:-

Curtonotus elegans, Salter, in Jukes's Manual, as above quoted.

C. rotundatus, Salter, Expl. l.c. p. 11, Co. Cork, Ardgroom.

C. elongatus, Salter, Old Head of Kinsale, Dunworley Bay.

These are, on an average, $1 \frac{1}{2}$ inch wide; and there are some still larger species in the Irish cabinets.

Generic Characters.-In the typical species, C. elegans, from Angle Bay, Pembrokeshire, the beaks are prominent and placed at the anterior fourth. In one of the species from Co. Cork thes are low and nearly halfway from the anterior end. In $C$. elongatus they orerhang the anterior side. However they may be placed, beneath them in each valve is a thickened hinge-plate with a single strong triangular central tooth, smooth-edged, and not indented below as in Schizodus. In the left valve this tooth lies behind the deep notch for the corresponding and equally large tooth in the right valve, this being in front of it; and in the right valve only is there an obscure tooth behind the central one. There are no remote cardinal teeth, nor hinge-lamella for the support of a ligament, which it seems must have been external. The anterior muscular scar is deep, the posterior less excavated, and placed far inwards; the pallial impression is entire, at a considerable distance from the edge in most of the 
1863.]

SALTER-UPPER OLD RED SANDSTONE.

species. A thick low ridge extends from the hinge-plate behind the anterior muscular scar.

Curtonotus etegans, Salter. Figs. $3 a, 3 b$. Jukes's Manual, 2nd edit. p. 508, fig. 14, $f$.

An inch wide, gently convex, regularly oval, not very thickshelled; beak small; nearly overhanging the anterior side; pallial line near the margin. Surface smooth. Cardinal tooth oblique; hinge-plate moderate.

Co. Cork (Pilton group), Dunworley Bay. In the Mus. Irish Industry.

Figs. 3-5.-Shells from the Pilton Group.
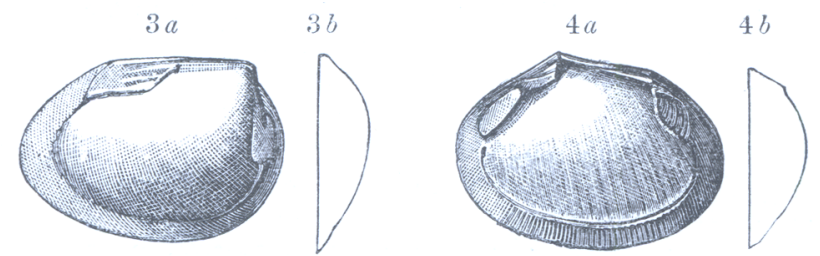

$5 a$
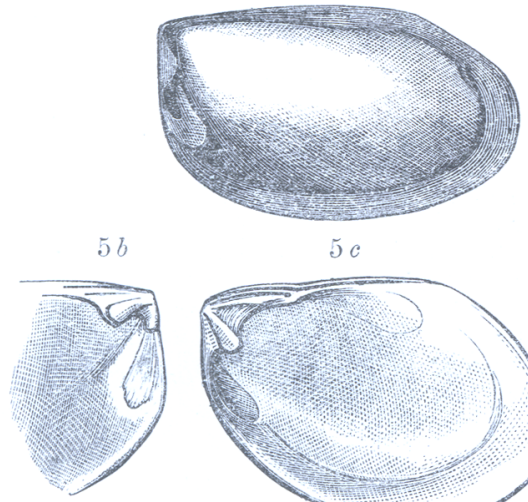

$5 c$
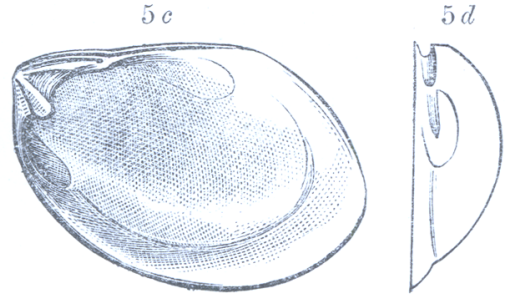

Curtonotus, three species: $-3 a, 3 b$. C. elegans. 4a,4b. C. centralis.

$5 a-5 d$. . Clongatus.

Curtonotus Unio, spec. nov.

Round-ovate, not pointed at either end, about 1 inch high and $1 \frac{1}{4}$ long, gently convex, the beak rather prominent and nearly overhanging the anterior end. A broad callosity runs vertically from beneath it within the shell. Anterior muscular scar small, but deep; posterior placed high up, distinct, oval. Pallial border not very near the edge; shell thick about the hinge. Cardinal teeth narrow, nearly direct.

West Angle Bay, W. Pembrokeshire, in the lowest Carboniferous 
Shale, or upper part of the Pilton group. In the Mus. Pract. Geology.

Curtonotus centralis, spec. nov. Figs. $4 a, 4 b$.

Transversely oval, rather thick-shelled, convex; the low beak more than one-third from the anterior end. Cardinal tooth direct; hinge-plate moderately thick. Pallial scar rather near the margin.

From the Pilton group, N. of Enniskeen, co. Cork. In the Mus. Irish Industry.

Cortonotus elongatus, Salter. Figs. $5 a-5 d$.

Transversely oval, gibbous from the prominent beak, which is terminal, and overhangs the short oblique anterior end. Hinder margin rounded. Breadth to length as 7 to 13 . Surface concentrically striate. Hinge-plate triangular, thick, with a large tooth in either valve, and a very small secondary anterior one in the left valve.

From the Pilton group, Co. Cork. Townland of Leheragh, Dunworley Bay. Bear Island, Kerry. Old Head of Kinsale. In the Mus. Irish Industry.

I also subjoin a description of the Serpula from the Upper Old Red Sandstone, above mentioned, p. 476.

Fig. 6.-Mass of Serpula advena, from the Upper Old Reil of Caldy Island, West side (natural size).

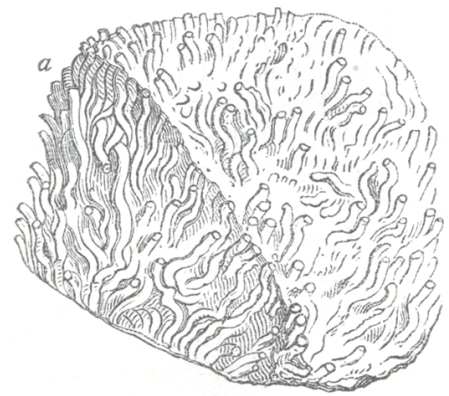

Serpula ADVENa, spec. nov. Fig. 6.

Short wavy cylindrical tubes, one-third of a line wide, and about one inch long, closely aggregated, ascending. The surface is smooth, or, at least, not roughly ridged $(a)$. The state of preservation does not permit me to say whether the surface is quite smooth, or marked with lines of growth. The tubes are filled with solid carbonate of lime, and lie in a red sandy matrix.

This species occurs 40 feet below the uppermost bed of the old Red Sandstone, in Sandtap Bay, west of Caldy Island, Pembrokeshire, whence it was collected by me in 1854; also in beds of the same age at West Angle, Pembrokeshire. 